\title{
Optimalisasi Media Sosial Pesantren untuk Membendung Konten Negatif di Dunia Maya
}

\author{
Achmad Farid \\ Fakultas Dakwah dan Komunikasi Islam \\ Institut Agama Islam Syarifuddin Lumajang \\ ac.faried@gmail.com
}

\begin{abstract}
The emergence of new media era allows the spread of positive contents (inspiring and useful subject) and negative contents (hate speech and hoaxes) through cyberspace. Islamic Boarding Schools (Pondok Pesantren) which have large mass of santri (students) have a strategic position to repress the dissemination of mentioned negative content. The applied method is optimizing social media as a channel for spreading positive content with the spirit of rahmatanlil 'alamin.
\end{abstract}

Keywords: New Media, Islamic Boarding School (Pondok Pesantren), the Spirit of Rahmatanlil 'Alamin

\section{PENDAHULUAN}

Era new media (media baru) lahir dengan munculnya jaringan internet. Tak hanya muncul, internet menyentuh semua lapisan masyarakat secara masif dan terstruktur. Hingga saat ini, nyaris tidak ada lagi titik di muka bumi, yang tak tersambangi sinyal internet. Pada masa kini, arus informasi bergerak cepat, dengan sumber yang variatif, dan dapat disalurkan ke banyak sasaran. Apalagi, berkat teknologi ini pula, lahir pula jejaring/media sosial seperti Facebook, Twitter, Instagram, maupun Youtube. Gegap gempitanya tidak hanya di luar negeri atau tempat penciptaannya, melainkan sampai ke Indonesia.

Terdapat 326 juta telepon seluler yang aktif di Indonesia, dengan 66 juta di antaranya dipakai untuk mengakses media sosial. Rata-rata, seseorang mengakses 
internet per hari melalui PC/komputer selama 4 jam 42 menit, melalui telepon seluler selama 3 jam 33 menit. Sedangkan seseorang mengakses media sosial per hari melalui telepon seluler selama 2 jam 51 menit. Popularitas televise sebagai media sumber informasi terdegradasi secara signifikan. Masih berdasarkan riset yang sama, per hari, seseorang mengakses internet melalui PC/komputer selama 4 jam 42 menit, dan mengakses internet melalui telepon seluler selama 3 jam 33 menit, sedangkan untuk menyaksikan televisi, rata-rata per orang dalam sehari "hanya” 2 jam 22 menit.

Para pemakai internet memiliki latar belakang usia yang berbeda. Mulai mereka yang berumur muda (18-25 tahun) dan digolongkan sebagai digital natives, hingga mereka yang berusia lanjut pada kisaran 65 tahun. Digital natives tercatat sebagai pengguna dengan jumlah terbanyak (49 persen). Disusul mereka yang berusia di rentang 26-35 tahun (33,8 persen), 36-45 tahun (14,6 persen), 46-55 tahun (2,4 persen), dan 56-65 tahun (0,2 persen).

Sementara itu, dokumen pendidikan islam kementerian agama menjelaskan, istilah Pondok Pesantren merupakan dua istilah yang menunjukkan satu pengertian. Pesantren menurut pengertian dasarnya adalah tempat belajar para santri, sedangkan pondok berarti rumah atau tempat tinggal sederhana terbuat dari bambu. Disamping itu, kata pondok mungkin berasal dari Bahasa Arab Funduq yang berarti asrama atau hotel. Di Jawa termasuk Sunda dan Madura umumnya digunakan istilah pondok dan pesantren, sedang di Aceh dikenal dengan Istilah dayah atau rangkang atau menuasa, sedangkan di Minangkabau disebut surau.

Secara umum Pondok Pesantren didefinisikan sebagai lembaga pendidikan yang memiliki 5 elemen pokok; (1) Pondok/Asrama: adalah tempat tinggal bagi para santri. Pondok inilah yang menjadi ciri khas dan tradisi pondok pesantren dan membedakannya dengan sistem pendidikan lain yang berkembang di Indonesia, (2) Masjid: merupakan tempat untuk mendidik para santri terutama dalam praktek seperti shalat, pengajian kitab klasik, pengkaderan kyai, dll, (3) Pengajaran kitab-kitab klasik: merupakan tujuan utama pendidikan di pondok pesantren, (4) Santri: merupakan sebutan untuk siswa/murid yang belajar di pondok pesantren, dan (5) Kyai: merupakan pimpinan pondok pesantren. Kata kyai sendiri adalah gelar yang diberikan masyarakat kepada seorang ahli agama Islam yang menjadi pimpinan pesantren dan mengajarkan kitab-kitab klasik. (Tradisi Pesantren : Zamakhsyari Dhofier, 1982). 
Populasi Pondok Pesantren terbesar berada di Provinsi Jawa Barat, Jawa Timur, Jawa Tengah dan Banten yang berjumlah 78,60 persen dari jumlah seluruh Pondok Pesantren di Indonesia. Dengan rincian Jawa Barat 28,00 persen, Jawa Timur 22,05 persen, Jawa Tengah 15,70 persen, dan Banten 12,85 persen. Berdasarkan data dari Direktur Pendidikan Diniyah dan Pondok Pesantren Kementerian Agama Ahmad Zayadi (2017), terdapat peningkatan jumlah pondok pesantren yang signifikan tiap tahun. Pada 1977 jumlah pesantren berjumlah sekitar 4.195 buah dengan jumlah santri sekitar 677.394 orang. Jumlah ini mengalami peningkatan berarti pada tahun 1985, di mana pesantren berjumlah sekitar 6.239 buah dengan jumlah santri mencapai sekitar 1.084 .801 orang.

Pada 1997, Kementerian Agama mencatat jumlah pesantren sudah mengalami kenaikan menjadi 9.388 buah, dan kenaikan jumlah santri sampai sekarang hingga berjumlah 1.770 .768 orang. Berdasarkan data statistik Ditjen Kelembagaan Islam, Departemen Agama Republik Indonesia pada tahun 2001 ada 11.312 pesantren dengan 2.737.805 santri. Kemudian pada tahun 2005 jumlah pesantren kembali meningkat menjadi 14.798 pesantren dengan santri berjumlah 3.464 .334 orang. Sementara, berdasarkan data Bagian Data, Sistem Informasi, dan Hubungan Masyarakat Sekretariat Direktorat Jenderal Pendidikan Islam Kementerian Agama, pada tahun 2016 terdapat 28,194 pesantren yang tersebar baik di wilayah kota maupun pedesaan dengan 4,290,626 santri.

Apa yang disampaikan di atas, menjadi latar belakang penulisan artikel ini. Bahwa potensi media sosial pesantren, yang beroperasi di dunia maya berbasis internet terbilang besar. Sehingga, sudah selayaknya dimanfaatkan. Ada sejumlah riset terdahulu yang dijadikan referensi, antara lain, penelitian yang berjudul Optimalisasi Penerapan eGovernment melalui Media Sosial dalam Mewujudkan Good Governance (Sucika, 2016). Dalam riset yang diterbitkan di Prosiding Seminar Nasional Komunikasi itu, terdapat penjelasan tentang pentingnya peran media sosial dalam pelaksanaan e-Government. Sedangkan riset kali ini, berbicara hal yang sama dengan subjek yang berbeda, yakni, tentang pentingnya optimalisasi media sosial di Pondok Pesantren. Salah satu karakteristik media sosial adalah kemampuan untuk membawa perubahan sosial. Sedangkan Pondok Pesantren memiliki kemampuan menyentuh masyarakat.

Penelitian yang juga dijadikan rujukan adalah artikel di Jurnal The Messenger yang berjudul Komunikasi dan Media Sosial (Watie, 2011). Dalam riset tersebut, dijelaskan 
bahwa media sosial melingkupi setidaknya dua level komunikasi, yakni komunikasi interpersonal, dan komunikasi massa. Melalui komunikasi interpersonal, dua pihak yang sedang berkomunikasi akan merasa lebih dekat dan dapat lebih terbuka. Sedangkan di sisi lain, media sosial dapat menjadi sarana komunikasi massa yang efektif karena dapat menjangkau masyarakat seluas-luasnya. Membangun kedekatan dengan khayalak, sekaligus menyebarkan informasi seluas-luasnya, perlu dilakukan oleh Pondok Pesantren yang tergolong agen of change dan memiliki potensi besar untuk menebarkan semangat positif di masyarakat.

\section{PEMBAHASAN}

Michael Gamble dan Teri Kwal Gamble (2002) menjelaskan tentang empat ciri fenomena media sosial. Pertama, pesan yang disampaikan tidak hanya untuk satu orang, tapi untuk banyak orang atau bisa diakses oleh banyak orang. Kedua, pesan yang disampaikan bebas tanpa melalui sistem sortir, baik berupa editing maupun gatekeeper. Ketiga, pesan yang disampaikan cenderung lebih cepat dibanding media lainnya. Keempat, penerima pesan yang menentukan waktu interaksi. Dari semua pandangan di atas, dapat disimpulkan tentang betapa kuatnya potensi media sosial untuk memengaruhi masyarakat, termasuk peluangnya menjadi media untuk memberikan narasi baru pada masyarakat melalui kanal-kanal yang beragam dan banyak jumlahnya. Maka itu, mengisi media sosial dengan konten yang baik, lantas menyebarkan konten itu secara masif adalah langkah kongkret untuk menebar pesan-pesan positif. Dalam bahasa keislaman, konten tersebut merupakan pesan yang berdaya untuk menjadikan tiap muslim agen penyear rahmatan lil 'alamin.

Pondok Pesantren harus melek dengan kondisi ini. Apalagi, saat ini terdapat banyak akun ataupun komunitas yang mengatasnamakan Islam, atau paling tidak mengklaim bahwa dirinya mewakili Islam, namun di media sosial, tidak menampakkan akhlak keislaman. Jumlah Pondok Pesantren yang sedemikian besar di Nusantara ini, bisa menjadi agen produksi konten-konten positif di media sosial. Asalkan, media sosial Pondok Pesantren dikelola dengan baik, istiqomah, dan tidak partisan atau tersandera kepentingan golongan tertentu. 
Internet merupakan teknologi yang menawarkan digitisation, convergence, interactivity, dan development of network terkait pembuatan pesan dan penyampaian pesan yang terjadi melalui medianya. Adanya interaktifitas ini memungkinkan pengguna memiliki pilihan tentang informasi apa yang ingin dikonsumsi, sekaligus mengendalikan keluaran informasi yang dihasilkan, serta melakukan pilihan-pilihan lain sesuai keinginannya. Internet telah melahirkan new media, yang memungkinkan penggunanya untuk menggunakan ruang dan memerluas jaringan seluas-luasnya bahkan menunjukkan identitas yang lain dengan yang dimiliki pengguna tersebut di dunia nyata (Flew, 2002: 1125).

Ada sejumlah karakteristik media baru, antara lain: (1) Multimedia, dapat memuat atau menyajikan berita atau informasi dalam bentuk teks, audio, video, grafis, dan gambar secara bersamaan (2) Aktualisasi, berisi informasi aktual karena kemudahan dan kecepatan penyajian (3) Cepat, begitu diposting atau di unggah, langsung bias diakses semua orang (4) Upd ate, pembaruan (updating) informasi dapat dilakukan dengan cepat baik dari sisi konten maupun redaksional, misalnya kesalahan ketik atau ejaan (5) Kapasitas luas, halaman web bias menampung naskah sangat panjang (6) Fleksibilitas, pemuatan dan editing naskah bisa kapan saja dan dimana saja, juga jadwal terbit (update) bias dilakukan setiap saat (7) Luas, menjangkau seluruh dunia yang memiliki akses Internet (8) Interaktif, dengan adanya fasilitas kolom komentar dan chat room. (9) Terdokumentasi, informasi tersimpan di "bank data" dan dapat ditemukan ketika diperlukan dan (10) Hyperlinked, terhubung dengan sumber lain (links) yang terkait dengan informasi tersaji (Syamsul: 2012: 11).

Karakteristik di atas jelas sudah mengungguli media konvensional yang umumnya memiliki keterbatasan bila secara head to head dihadapkan dengan sepuluh karakteristik media baru tadi. Terlebih, media baru juga sudah mengilhami munculnya aneka media sosial yang telah akrab dengan masyarakat di era kekinian. Media sosial sanggup “merombak" banyak pemikiran dan teori sosial yang sebelumnya sudah ada. Media sosial memberi peluang bagi tiap individu untuk mengeluarkan pendapat.

Ardianto dalam pengantar di buku Komunikasi 2.0 (Aspikom, 2011) mengemukakan, media sosial memiliki kekuatan sosial yang sangat mempengaruhi opini publik yang berkembang di masyarakat. Penggalangan dukungan atau gerakan massa bisa terbentuk karena apa yang ada di dalam media sosial, terbukti mampu membentuk 
opini, sikap dan perilaku publik atau masyarakat. Fenomena media sosial ini bisa dilihat dari kasus Prita Mulyasari versus Rumah Sakit Omni International.

Wakefield dkk (2011) merumuskan delapan tujuan media sosial. Pertama, mengomunikasikan pesan. Kedua, pertukaran pengetahuan dan pelaporan. Ketiga, mengatasi hambatan inklusi bagi kelompok masyarakat yang selama ini terpinggirkan, sebab dengan menggunakan media sosial semua kelompok bisa melakukan komunikasi yang setara. Keempat, menghubungkan semua elemen masyarakat tanpa terkecuali.

Kelima, meningkatkan penyampaian pelayanan. Keenam, penskalaan yang cepat atau pelibatan semua stakeholder dapat dilakukan dengan cepat. Mereka yang saling terhubung dalam skala kepentingan yang sama, dapat berinteraksi, berkomunikasi, dan berkontribusi sesegera mungkin. Ketujuh, memercepat penggalangan dana. Kedelapan, mendukung trasparansi dan akuntabilitas.

Media sosial membentuk interaksi sosial. Sehingga memungkinkan para pengguna untuk berhubungan satu dengan lainnya dan membentuk komunitas-komunitas untuk bersosialisasi, berbagi informasi, atau untuk mencapai suatu tujuan atau kepentingan bersama. Media sosial dapat memberdayakan para penggunanya karena memberikan platform untuk berkomunikasi. Hal ini memungkinkan siapa pun dengan akses Internet memiliki kemampuan untuk mempublikasikan atau menyiarkan informasi sebagai media demokratisasi yang efektif. Dalam hal waktu, teknologi media sosial memungkinkan pengguna untuk segera mempublikasikan informasi setiap saat.

Semua Pondok Pesantren dan elemen-elemen yang ada di dalamnya, mulai dari santri hingga alumni, adalah potensi besar yang dimiliki Indonesia, yang dapat berdaya guna untuk menggerus jumlah hoax dan ujaran kebencian di dunia maya. Bila dari jumlah yang disampaikan di atas per 2016 atau sekitar 28 ribu Pondok Pesantren, sepuluh persennya saja aktif di media sosial pada tiga platform populer saja (facebook, instagram, dan youtube), artinya ada tak kurang dari 2.800 sumber informasi yang baik di Indonesia, yang siap di optimalkan. Serta, ada sekian banyak santri dan alumni yang dapat ikut menyebarkan pesan-pesan positif yang dimaksud. Mungkin santri yang sedang belajar di Pondok Pesantren tidak memiliki banyak banyak akses pada media sosial. Namun tatkala hari libur, akses itu kembali terbuka, atau paling tidak, alumni pasti memiliki akses yang jauh lebih luas. Yang juga perlu diingat, konten positif selalu memiliki massa, khususnya, mereka yang beragama Islam. Sehingga, yang berpeluang menjadi pengikut, penyuka, 
ataupun pembagi konten-konten positif dari media sosial Pondok Pesantren, tidak terbatas dari kalangan Pondok Pesantren itu saja.

Media sosial Pondok Pesantren yang jumlahnya sedemikian banyak, memiliki potensi besar untuk menggiling atau menggerus eksistensi berita hoax di dunia maya. Meski memang, strategi ini bukan satu-satunya elemen yang dapat berperan. Karena problem ini begitu kompleks dan sering kali menyangkut banyak kepentingan (mulai komersial, budaya, politik, bahkan proxy war). Namun, bila elemen yang satu ini digelorakan, peran dan pengaruh positifnya bakal terstruktur dan menyejukkan.

\section{KESIMPULAN}

Langkah apa saja yang bisa dilakukan media sosial Pondok Pesantren untuk ikut mereduksi arus berita hoax atau banjir ujaran kebencian di dunia maya? Pertama, media sosial perlu rutin mengeluarkan kabar positif atau berita baik. Tentang apa? Tentang kampus, warganya, atau kabar lain seputar kehidupan Pondok Pesantren yang pasti bernuansa kebaikan serta bernafas keislaman. Konten-konten positif bisa berbentuk tulisan maupun poster digital, foto, atau meme. Yang jelas, isinya adalah tentang kalamkalam dakwah, ajakan untuk menuju hidup yang arif dan lestari, serta lain sebagainya. Bisa pula, berupa artikel para guru atau kyai. Bisa pula, artikel santri yang berisi kebaikan dan dapat dipertanggungjawabkan.

Bisa diperkirakan, apabila secara konsisten tiap satu Pondok Pesantren membuat satu konten saja dalam sehari, akan ada 2.800 konten inspiratif yang tercipta dan siap disebarkan. Yang jelas, para alumni, guru atau ustadz, dan para pengurus yang bisa mengakses media sosial mesti diarahkan untuk turut menyebarkan konten tersebut di akun media sosialnya masing-masing. Internal Pondok Pesantren harus aktif, selayaknya filosofi koperasi. Koperasi hanya bisa hidup langgeng dengan sokongan dari para anggota.

Media sosial Pondok Pesantren bakal bisa terus eksis dengan dukungan warga atau elemen dari internal terlebih dahulu, setelah itu, bisa bergaung ke pihak luar. Optimalisasi media sosial ini tidak hanya mendayung ke satu pulau. Sebab, ada banyak manfaat lain yang bisa diraih oleh Pondok Pesantren. Misalnya, dengan mengaitkannya di 
aspek promosi, agar Pondok Pesantren itu lebih dikenal publik. Jadi, ada mekanisme branding di dalam upaya optimalisasi tersebut.

\section{REFERENSI}

Aspikom. Komunikasi 2.o. Yogyakarta: Mata Padi Pressindo, 2011

Flew, Terry. New Media: An Introduction. New York: Oxford University Press, 2002

Gamble, M. \& Teri K. G. Communication Works. Boston: McGraw Hill Education, 2002

Lincoln, Yvonna S \& Egon G. Guba. Naturalistic Inquiry. California: Sage, 1985.

Lindlof, T.R, \& Taylor B.C. Qualitative Communication Research Methods, Edisi 2. California: Sage Publications, 2002.

Wakefield, Daisy., Sklair, Aphra.,\&Gibson, Andy. Philanthropy and Media Social. The Institute of Philanthropy, 2011. Tautan http://www.tpw.org/images/ files/ philanthropy_ and_social_media.pdf diakses pada 20 Desember 2017

Yin, Robert K. Case Study Research: Design and Methods. London: Sage Publication, 2003.

"Analisis dan Interpretasi Data pada Pondok Pesantren, Madrasah Diniyah (Madin), Taman Pendidikan Qur'an(TPQ) Tahun Pelajaran 2011-2012", tautan http://pendis.kemenag.go.id/file/dokumen/pontrenanalisis.pdf diakses pada 30 April 2018

"Pertumbuhan Pesantren di Indonesia Dinilai Menakjubkan", Republika, 30 November 2017, tautan http://republika.co.id/berita/dunia-islam/islam-nusantara/17/11/30/po88lk396pertumbuhan-pesantren-di-indonesia-dinilai-menakjubkan diakses pada 29 April 2018 